"The method of stock selection with the intention of portfolio formation"

\begin{tabular}{|c|c|c|}
\hline AUTHORS & $\begin{array}{l}\text { Bahram Biglari } \\
\text { Mohammad Nazaripour }\end{array}$ & \\
\hline ARTICLE INFO & \multicolumn{2}{|c|}{$\begin{array}{l}\text { Bahram Biglari and Mohammad Nazaripour (2016). The method of stock } \\
\text { selection with the intention of portfolio formation. Problems and Perspectives in } \\
\text { Management, 14(3-si), 429-438. doi:10.21511/ppm.14(3-si).2016.18 }\end{array}$} \\
\hline DOI & \multicolumn{2}{|c|}{ http://dx.doi.org/10.21511/ppm.14(3-si).2016.18 } \\
\hline RELEASED ON & \multicolumn{2}{|l|}{ Thursday, 15 September 2016} \\
\hline JOURNAL & \multicolumn{2}{|c|}{ "Problems and Perspectives in Management" } \\
\hline FOUNDER & \multicolumn{2}{|c|}{ LLC “Consulting Publishing Company "Business Perspectives" } \\
\hline & & $\begin{array}{l}= \pm \\
=\Xi \\
=-5\end{array}$ \\
\hline NUMBER OF REFERENCES & NUMBER OF FIGURES & NUMBER OF TABLES \\
\hline
\end{tabular}

(C) The author(s) 2022. This publication is an open access article. 
Bahram Biglari (Iran), Mohammad Nazaripour (Iran)

\title{
The method of stock selection with the intention of portfolio formation
}

\begin{abstract}
The purpose of this study is comparing the method of selecting and forming portfolios. The methods are Capital Assets Pricing Model, Fama and French Model and Excess return model. The methods are transacted in four steps: expected return estimation, stock valuation, selecting portfolios and estimating all kinds of portfolios' returns and risk. In the point of forming portfolios, the decision variables were estimated to compare the methods. There are two questions: are the portfolio forming methods significant at Tehran Security Exchange? And, are there significant differences between methods with the view of generating Expected Rate of Return, Real Return, Risk, Differential Extents of market return and risk-free return? Multivariate Regression, One Way ANOVA and Correlations Tests are used to analyze and test models. The research finding shows that the models have the ability to perform significantly in Tehran Security Exchange. The models were significantly different in five important measures. They are risk, the future actual return, expected return in short and long terms. Finally, it was evidenced that not only there are significant differences between the three models, but also Excess return method was more efficient than the other models.
\end{abstract}

Keywords: expected return, intrinsic value, book value, market value, firms' size.

JEL Classification: D46, G12, G14, G30, G32.

\section{Introduction}

Capital markets are one of the main pillars of economic progress and development. Those markets as a low resource of capital cost not only can bestir the economy, but also can lead it (Haugen R., 1995). The capital markets can gather errant fiscal resource of the economy and make use of it to optimal allocation resource (Haugen R., 1995; Fama, E.F., 1998). The Tehran Security Exchange is emanation of Iran capital markets and has been considered Iran capital markets and, as a result, it has been considered by the researches all over the Iran. The Tehran Security Exchange is a newly established market, even though it has been working for 40 years with a lot of turbulences in these years. More studies and researches are necessary to be done to improve and develop condition of the capital markets to help this sector of economy. The key facility of capital markets is investors and one of the most important ways to exhort them to attend into these markets is reducing the risk of their investment (Fama \& French, 1993). The risk reduction depends on accuracy, pellucidity and conclusiveness of investment strategies (Tudor, 2009). These strategies are designed with methods and approaches of capital assets selection. Thus, we know the importance of stock selection models and portfolio selection. The main importance of this research would be doing all of the steps of stock selection and portfolio formation and observing of future factual results by simulation accurately. It must be according to financial and statistical knowledge principals and empirical researches.

(C) Bahram Biglari, Mohammad Nazaripour, 2016.

Bahram Biglari, Department of Accounting and Finance, Islamic Azad University, Aliabad Branch, Golestan, Iran.

Mohammad Nazaripour, Department of Accounting, University of Kurdistan, Sanandaj, Iran.

\section{Literature review}

The theories of portfolio and investment emerged, while portfolio model was formatting by Markowitz (1959), Sharpe (1964) Lintner (1965) and Mossin 1972, Black, Jensen and Scholes tested The Capital Asset Pricing Model and confirmed it. In 1973, Macbeth, Fama, Friend and Bloom also confirmed CAPM (Fama \& French, 1992; Haugen R., 1993; Reilly \& Brown, 2003).

Then, in 1977, Roll (1983) criticized to CAPM and its tested especially both latest models that funded to directed disruption the tests, then, the age of tests entered to new step (Roll \& Ross, 1994; Reilly \& Brown, 2003). Despite Cheng, Grower and Gibbons tested CAPM and rejected it, enter the criticism of their methodology (Fama \& French, 2004; Rizwan \& Rehman, 2014). As for, in 1983, Markowitz (1959) did not believed to success of empirical testes for practical use of The Capital Asset pricing models and The portfolio model (Haugen R., 1993). Fama and French studied effect of firm size and book-to-market equity beside market return on stock return in NYSE and finding showed that firm size has inverse relationship alone to stock return, but it has direct relationship alongside other variable. This research performed by observed many of stock which has too much role in variability of weighted index (Fama \& French, 1995; Dennis, Perfect, Snow \& Wiles, 1995).

In the model submitted at 1995 by Fama and French, in addition of CAPM's independent variable, they have taken into consideration many other factors include: Firm size, E/P, CF/P, Book-to-Market Equity, Past Sales Growth, Long-term Past Return, and Past Short-term Return. Consequently, they found out that the Fama and French's three factor models contains all exceptional relevance to mean of return mentioned in 
CAPM, except continuation of Past Short-term Return (Fama \& French, 2004; Reilly \& Brown, 2003).

In the Fama's study in 1998 that were due on value and stock growth in international markets field at twenty years period (1975-1995), it was found that the return resulting from value of out of money stock, are more than the return of the stock price that have faster growing. According to the mentioned period, differential average returns of international portfolio was $7.68 \%$ between high and low ratio of Book-toMarket value. In addition value of out of money stocks had surpassed growing of the stock price that have fast grows. On the other hand, CAPM cannot explain risk premium on throughout of international markets, but a two-factor model include risk factors can consider risk premium in estimating return all over the markets (Fama, E.F., 1998; Fama \& French, 1998).

After that a research was done and confirms Fama and French's result by Dennis and others in 1995. They not only confirmed the optimal combination involved portfolios of small firms with high BV/MV ratios, but also showed that this superiority prevailed after assuming 1 percent transaction costs and annul rebalancing Dennis, Perfect, Snow \& Wiles, 1995).

1.1. Research design. The methodology was designed on a basis of the best and valid method from financial research. In addition, we designed a method that the models and hypothesis are testable and comparable to use the result in Security Exchange. This is a simulation test for examining models as empirical with points of actual time that investor supposed to make a decision in process of portfolio forming. Time period of research divided into two sub periods that the first has begun from March $21^{\text {st }}$ of 2003 to March $20^{\text {th }}$ of 2008. The data of this set are utilized to estimate required variable include beta and growth rate of dividend per share. Second has begun from March $21^{\text {st }}$ of 2008 to March $20^{\text {th }}$ of 2013.

These years are utilized to do tests and to form, select and make portfolios. Consider that we use data of five years to test models in point of time on sub period of times. Twelve months are added to observe the real return of latest portfolio. They are from $21^{\text {st }}$ March of 2013 from $20^{\text {th }}$ March of 2014. On the whole, our period of time series is eleven years. There are chosen twenty points in second sub period to select stocks and form (create) portfolios. The first point is selected by random, but other points (19 points) are selected by systematic method with an order of one point in per three months. The reason of three months for a one observation is that the variations of effective factors on volatility trend of return of stocks are very clear, so market return and stock return would have observable variation about price and return. First point for testing models and making portfolios is $19^{\text {th }}$ June of 2008 .
Limited territory (region) of research is Tehran Security Exchange and statistical population is all accepted common stocks (all firms listed) of there.

Statistic sample was selected through 446 stocks by systematic method based on several rules which gathered from valid and reliable researches. Kinds of stocks in population have omitted because of rules and principals. At the end of sampling process, we have 55 statistic samples contain required conditions and data. The samples must not be investment, insurance, banking and holding institute or firms. It is because of the financial structure and dividing per share earn that are different. Samples should be stock of the firms with fiscal year-end at $20^{\text {th }}$ March. It is because of the January Effect that samples have a same price variation. In Iran, fiscal year-ends are at $20^{\text {th }}$ March. We selected the firms that have accepted in Security Exchange before research period. If firm's stocks didn't have trading interruptions, stocks price should have at least minimum of Tick Size.

In twenty points of years for each stock and each models, we estimated Beta by regression used three months data at the five time series. In the following, there are Frequency Distributions of samples in Table 1 that are resulted by the filtering process.

Table 1 . The result of filtering

\begin{tabular}{|l|c|}
\hline All firms before sampling & 446 \\
\hline Investment institute & 50 \\
\hline Firms that don't have fiscal end-year at 20th March & 166 \\
\hline Firms didn't accept before research period & 173 \\
\hline Interrupted and low tick size firms & 135 \\
\hline Statistical sample & 55 \\
\hline
\end{tabular}

1.2. Methodology. This research comprises four steps. First, computing expected rate of return at each point for three models that we use formulas for CAPM and Fama \& French models. In the Excess return method, we estimate basic return as expected rate of return (Jensen, 1968; Haugen R., 1993). After this step, Excess return method will be different with other models. Expected rate of return is discounted to calculate instinct value of stocks at each point by CAPM and Fama \& French models basis on expected rate of return. Vital factor to valuation based on Dividend Yield that would create and is expected. Dividend Discount Model is used by the Gordon equation (Haugen R., 1993; Reilly \& Brown, 2003). According to the following equation 1 :

$v=\frac{D_{0}(1+g)}{k_{e}-g}$

where $v$-is intrinsic value of each stock at per point of year of period;

$D_{0}-$ is dividend yield at present year including Dividend per Share, Stock Dividend and Warrant; 
So, $\left[D_{0}(1+g)\right]$ makes expected dividend yield at future year;

$k_{e}$ - is expected rate of return that was estimated by CAPM and Fama \& French models (Dennis, Perfect, Snow, \& Wiles, 1995).

Growth rate of Dividend per Share is estimated separately for each stock and each year by following equation 2:

$g=\sqrt{\frac{D_{1}}{D_{0}}}-1$,

where $g-$ is estimated at $t$;

$D_{1}-$ is estimated at $t-1$ and $D_{0}$ at $t-2$.

Thus, $g$ is stable at the four point of a year and each model (Reilly \& Brown, 2003). On the other hand, after estimating basic rate of return and differential return (historical Alpha) in Excess return method, we can create and form the portfolios in the four points of year at five years. Fundamental principal for selecting stock is Alpha (Jensen, 1968). We chose the stocks that have maximum coefficient of Alpha and we will try to make a portfolio contain about 25 to 30 securities at each point.

Second step would finish after calculating the value of per stock for CAPM and Fama \& French model at the points. Third step is begun in a process of computing the different value between intrinsic value and market value and portfolio making. In this step, we chose the stocks that the intrinsic value of them is bigger than the market value. There should be approximately twenty five to thirty stocks in each portfolio (Roll, 1983). It is because of diversification, but, as a result of regression and differential value between intrinsic value and market value, in some portfolios, we have fewer than twenty five stocks. At the last of this step, we have twenty portfolios about each model. It is four portfolios in per year for each model, on the whole, sixty portfolios. We identify ten comparable variables to calculation processes at each point. Those comparable variables are the best and suitable for comparing portfolios. There is name of those variables in Table 2.

Table 2. Variables

\begin{tabular}{|l|l|}
\hline Historical alpha & $X_{1}$ \\
\hline Expected rate of return & $X_{2}$ \\
\hline Real return of future season & $X_{3}$ \\
\hline Real return of future year & $X_{4}$ \\
\hline Average of real returns of future season & $X_{5}$ \\
\hline Differences between real return and expected rate of return at short term & $X_{6}$ \\
\hline Differences Between real return and expected rate of return at long term & $X_{7}$ \\
\hline Differences between real return and market return at short term & $X_{8}$ \\
\hline Differences between real return and market return at long term & $X_{9}$ \\
\hline Systematic risk (beta) & $X_{10}$ \\
\hline
\end{tabular}

In this research, not only we test ability of models to determine and compare the excepted rate of returns, but also we compare ability of models to predict and estimate real rate of return. According to research's aims, there are two major hypotheses that both of them are related together. Second hypothesis depends on confirming the first hypothesis. We predict that:

- $\mathrm{a}_{1}$, the models and methods of selecting stock and forming portfolios are significant and established in Tehran Security Exchange.

- $\mathrm{a}_{2}$, there is a best efficient model between models and differences between them are significant.

1.3. Capital assets pricing model. The attraction of the CAPM is that it offers powerful and intuitively pleasing predictions about how to measure risk and the relation between expected return and risk (Sharpe, 1964; Lintner, 1965; Fama \& MacBeth, 1973; Fama \& French, 2004). The CAPM builds on the model of portfolio choice developed by Harry Markowitz. The Markowitz approach is often called a "mean-variance model" (Markowitz, 1959). Tests of the CAPM are based on three implications of the relation between expected return and market beta implied by the model. First, expected returns on all assets are linearly related to their betas, and no other variable has marginal explanatory power. Second, the beta premium is positive, meaning that the expected return on the market portfolio exceeds the expected return on assets whose returns are uncorrelated with the market return.

Third, in the Sharpe-Lintner version of the model, assets uncorrelated with the market have expected returns equal to the risk-free interest rate, and the beta premium is the expected market return minus the risk free rate (Sharpe, 1964; Lintner, 1965; Fama \& French, 2004). Sharpe (1964) and Lintner (1965) add two key assumptions to the Markowitz model to identify a portfolio that must be mean-varianceefficient. The first assumption is complete 3 agreements: given market clearing asset prices at $\mathrm{t}-1$, investors agree on the joint distribution of asset returns from t- 1 to $t$. And this distribution is the true one, that is, the distribution from which the returns we use to test the model are drawn. The second assumption is that there is borrowing and lending at a risk free rate, which is the same for all investors and does not depend on the amount borrowed, or lent (Fama \& French, 2004). The CAPM assumptions imply that the market portfolio $\mathrm{M}$ must be on the minimum variance frontier if the asset market is to clear. This means that the algebraic relation that holds for any minimum variance portfolio must hold for the market portfolio (Fama \& French, 2004; Dennis, Perfect, Snow \& Wiles, 1995). Specifically, if there are $\mathrm{N}$ risky assets, Minimum Variance Condition for M (Sharpe, 1964):

$$
E\left(R_{i}\right)=E\left(R_{Z M}\right)+\left[E\left(R_{M}\right)-E\left(R_{Z M}\right)\right] \beta_{i M} i=1, \ldots, N,
$$

where $E\left(R_{i}\right)$ - is the expected return on asset $i$ and $\beta_{i M}$, the market beta of asset $i$, is the covariance of its return 
with the market return divided by the variance of the market return, Market Beta:

$$
\beta_{i M}=\frac{\operatorname{COV}\left(R_{i}, R_{M}\right)}{\sigma^{2}\left(R_{M}\right)} \text {. }
$$

1.4. Sharp-Lintner CAPM. When there is risk free borrowing and lending, the expected return on assets that are uncorrelated with the market return $E\left(R_{Z M}\right)$ must equal the risk free-rate, $R_{f}$. The relation between expected return and beta, then, becomes the familiar equation (Sharpe, 1964; Lintner, 1965; Fama \& French, 2004):

$$
E\left(R_{i}\right)=R_{f}+\left[E\left(R_{M}\right)-R_{f}\right] \beta_{i M} i=1, \ldots, N,
$$

where $R_{f}$ - is the risk-free rate that interested rate of governmental bonds is used as $R_{f}$ in this research. In the period of research $R_{f}$ is changed at the middle of time. Consequently, we have used two rate of interest (Tudor, 2009);

$E\left(R_{M}\right)$ - is Market Portfolio rate of return and in this research TEDPIX ${ }^{4}$ is calculated as Market Portfolio rate of return.

The premium per unit of beta risk is $E\left(R_{M}\right)-R_{f}$ or Premium Market.

1.5. Three factors model of Fama and French. Fama and French argued that beta provided little information about the cross- section of common stock returns during the 1963-1988 periods. Instead, firm size and the BE/ME were important determinants of common stock returns (Fama \& French, 1998; Fama \& French, 2004; Dennis, Perfect, Snow \& Wiles, 1995). They confirm that size, earnings-price, debtequity and book-to-market ratios add to the explanation of expected stock returns provided by market beta. As a result, optimal portfolios are "multifactor efficient" which means they have the largest possible expected returns, given their return variances and the co variances of their returns with the relevant state variables (Fama \& French, 1995).

The returns on the stocks of small firms covers more with one another than with returns on the stocks of large firms, and returns on high book-to-market (value) stocks cover more with one another than with returns on low book-to-market (growth) stocks. Fama and French (1995) show that there are similar size and book-to-market patterns in the co variation of fundamentals like earnings and sales. Based on this evidence, Fama and French $(1993,1995)$ propose a three factor model for expected returns (Fama \& French, 2004). The equation of model is:

$$
\begin{aligned}
& E\left(R_{i t}\right)-R_{f t}=\beta_{i M}\left[E\left(R_{M t}\right)-R_{f t}\right]+\beta_{i s} E\left(S M B_{t}\right)+ \\
& +\beta_{i h} E\left(H M L_{t}\right)+\varepsilon_{i t},
\end{aligned}
$$

where $R_{i t}$ - is the return on security or portfolio $i$ for period $t$;

$R_{f t}$ - is the risk free return;

$R_{M t}$ - is the return on the value-weight (VW) market portfolio;

$S M B_{t}$ - is the return on a diversified portfolio of small stocks minus the return on a diversified portfolio of big stocks (small, minus and big s the difference between the returns on diversified portfolios of small and big stocks);

$H M L_{t}$ - is the difference between the returns on diversified portfolios of high and low $\mathrm{B} / \mathrm{M}$ stocks (high, minus and low is the difference between the returns on diversified portfolios of high and low $\mathrm{B} / \mathrm{M}$ stocks) and $\varepsilon_{i t}$ is a zero-mean residual.

The betas are slopes in the multiple regression of $R_{i t}$ $R_{f t}$ on $R_{M t}-R_{f t}, S M B_{t}$ and $H M L_{t}$. Treating the parameters in equation as true values rather than estimates, if the factor exposures $\beta_{i M}, \beta_{i s}$ and $\beta_{i h}$ capture all variation in expected returns, the intercept $\varepsilon_{i t}$ is zero for all securities and portfolios $i$ (Fama \& French, 1995; Fama \& French, 2004; Dennis, Perfect, Snow \& Wiles, 1995). One implication of the expected return equation of the three-factor model is that the intercept $\alpha_{i}$ in the time-series regression is zero for all assets $i$. Also $\varepsilon_{i t}$ is omitted by diversification.

$$
\begin{aligned}
& E\left(R_{i t}\right)-R_{f t}=\alpha_{i}+\beta_{i M}\left[E\left(R_{M t}\right)-R_{f t}\right]+ \\
& +\beta_{i s} E\left(S M B_{t}\right)+\beta_{i h} E\left(H M L_{t}\right)+\varepsilon_{i t},
\end{aligned}
$$

For estimating $S M B_{t}$, we use firm's monthly returns and then estimate average of monthly return of six portfolios. After that we obtain $S M B_{t}$, by this equation:

$$
S M B_{t}=\left[\frac{\left(\frac{S}{L}+\frac{S}{M}+\frac{S}{H}\right)}{3}\right]-\left[\frac{\left(\frac{B}{L}+\frac{B}{M}+\frac{B}{H}\right)}{3}\right] .
$$

And also for $H M L_{t}$ the differences between return of big and small firms with high BV/MV and return of big and small firms with low BV/MV. First, we estimate average of monthly return of four portfolios and, then, $H M L_{t}$ is estimated by this equation (Fama \& French, 1995; Fama \& French, 2004; Dennis, Perfect, Snow \& Wiles, 1995):

$$
H M L_{t}=\left[\frac{\left(\frac{S}{H}+\frac{B}{H}\right)}{2}\right]-\left[\frac{\left(\frac{S}{L}+\frac{B}{L}\right)}{2}\right] .
$$

1.6. Excess return model (differential return). This is a version of Capital Asset Pricing Model. This model is designed based on model of portfolio performance measurement. We use Jensen's model of portfolio performance measurement that it is utilizing 
Capital Asset Pricing Model to estimate basis rate of return for comparing portfolios (Jensen, 1968). Jensen was the first to note that the Sharpe-Lintner version of the relation between expected return and market beta also implies a time-series regression test. The SharpeLintner CAPM says that the expected value of an asset's excess return (the asset's return minus the riskfree interest rate, $R_{i t}-R_{f t}$ ) is completely explained by its expected CAPM risk premium (its beta times the expected value of $R_{m t}-R_{f t}$ ). This implies that "Jensen's alpha," the intercept term in the time-series regression and it is zero for each asset (Jensen, 1968; Dennis, Perfect, Snow \& Wiles, 1995). The equation of TimeSeries Regression is:

$$
R_{i t}-R_{f t}=\alpha_{i}+\beta_{i m}\left(R_{m t}-R_{f t}\right)+\varepsilon_{i t} .
$$

The calculations are done solitary for each stock, and then Jensen's Alpha (Historical Alpha) and basis rate of return are estimated. The stocks that have maximum rate of Alpha have better performance and we set them in portfolios. Basis rate of return is estimated by:

$$
\begin{aligned}
& R_{b}=R_{f}+\left[E\left(R_{M}\right)-R_{f}\right] \beta_{i M} \\
& \text { Alpha }=R_{i}-R_{b} .
\end{aligned}
$$

Historical Alpha is a difference between the average real rate of return through past time series and basis rate of return. Other variables are same to CAPM except $\beta_{i M}$ that is slope of regression line with $E\left(R_{M}\right)-R_{f}$ as independent variable and $\left(R_{i}\right)$ as dependent variable in CAPM, but, in this model, dependent variable is difference between $\left(R_{i}\right)$ and $\left(R_{f}\right)$ (Jensen, 1968).

1.5. Models' testing. In the first step we, use simple linear regression to estimate beta of stock return to market, size and BV/MV. The acceptable significant level is under 0.06 . We regress all stocks by three models at twenty points and stocks bring to next step, if they earn significant level under 0.06 otherwise dummy variables are added into models testing. Normality of data is measured by Kolomogorov-Smironov test over 0.5 and testing nonstandard residuals by P-P Plot. Data independency is measured by Durbin-Watson test and standardized residuals are tested by graphscatter in all regressions for testing homogeneity of residuals variance. Because of the Fama and French's multivariate linear regression, we have done Pearson Correlation Tests. Acceptable significant level is under 0.05 otherwise, one of the independent variables was omitted. We calculate variance, standard deviation, coefficient variation, semi variance and semi standard deviation for every ten variables at twenty perceived point of time period to use in final comparing. The latest tests are designed to measure significant differ of models according to generate real return, excepted rate of return, risk and other comparable variables. Then, we were comparing ten variables by ten tests in One Way ANOVA to observe behavior of models. We compared models two by two in Tukey-Kramer test, and the results were found.

\section{Result and discussion}

In CAPM, 342 exams were accepted by 1100 regressions and, on the whole, 270 stocks entered portfolios. Finding shows in $31 \%$ of times market, as a variable has the ability to clarify stocks' return and $24 \%$ of stocks have validity to be predicted by CAPM. In Fama and French's model, 342 exams were accepted by 1100 regressions and, on the whole, 267 stocks entered portfolios. Therefore, in 34\% of observations independent variables have significant ability to clarify stocks' return. Excess return model is stable and significant model to clarify stocks' return and is able to imply in empirical tests. In this model, $63 \%$ of stocks were able to make portfolios; it means the market has ability to clarify stocks' return.

Following, there are statistical results of comparing three models by the view of comparable measures from $\mathrm{X}_{1}$ to $\mathrm{X}_{10}$.

2.1. Historical Alpha, Jensen's measure, $X_{1}$. We predict the approaches to select and form portfolios are different in Historical Alpha. More formally:

$\mathrm{H}_{0}=$ the portfolio selection models won't have significant differences in Alpha generation.

$\mathrm{H}_{1}=$ the portfolio selection models will have significant differences in Alpha generation.

Table 3. ANOVA

\begin{tabular}{|l|c|c|c|c|c|}
\hline & $\begin{array}{c}\text { Sum of } \\
\text { squares }\end{array}$ & df & $\begin{array}{c}\text { Mean } \\
\text { square }\end{array}$ & $F$ & Sig. \\
\hline$X_{1}$ between groups & 798.861 & 2 & 399.430 & & \multirow{2}{*}{36.460} \\
\cline { 1 - 4 } Within groups & 624.453 & 57 & 10.955 & \\
\cline { 1 - 4 } Total & 1423.314 & 59 & & & \\
\hline
\end{tabular}

The test is accepted at three stars level and by the point of $\mathrm{Sig}=0.000, \mathrm{H}_{0}$ is rejected and it means three models are not similar to generate alpha. Alpha that is differential extent between real return and excepted rate of return is a measure of portfolio performance. By the following Table 4, the Alpha of Excess return model is 8.594182963 and it means this model is better than others by the view of Alpha measure.

Table 4. Alpha of Jensen mode

\begin{tabular}{|l|c|}
\hline \multicolumn{1}{|c|}{ Models } & Alpha \\
\hline Excess return & 8.594182963 \\
\hline Fama and french's model & 1.997051342 \\
\hline CAPM & 0.073265947 \\
\hline
\end{tabular}

Following Table 5 is comparing models two by two in Tukey-Kramer test. 
Table 5. T.K Test

\begin{tabular}{|l|c|c|c|c|c|}
\hline \multirow{2}{*}{ Dependent $(\mathrm{I}) \mathrm{k}(\mathrm{J}) \mathrm{k}$ variable } & \multirow{2}{*}{ Mean difference $(\mathrm{I}-\mathrm{J})$} & \multirow{2}{*}{ Std. error } & \multirow{2}{*}{ Sig. } & \multicolumn{2}{c|}{$95 \%$ confidence interval } \\
\cline { 4 - 6 } & & & & Lower bound & Upper bound \\
\hline $\mathrm{X}_{1}$ CAPM excess return & -8.252092 & 1.04668 & 0.000 & -11.0397 & -6.0022 \\
\hline CAPM Fama \& French & -1.92379 & 1.04668 & 0.167 & -4.4425 & 0.5950 \\
\hline Excess Return Fama \& French & 6.59713 & 1.04668 & 0.000 & 4.0784 & 9.1159 \\
\hline
\end{tabular}

According to Table 5 there are two significant differences between CAPM-Excess return and Excess return- Fama \& French. Historical Alpha is generated by Excess return is so significant different and shows Excess return is very reliable to predict expected rate of return and to form portfolios.

2.2. Expected rate of return, $X_{2}$. We expect that greater extent of expected rate of return will be generated by models differently.

Thus, $\mathrm{H}_{0}=$ the portfolio selection models won't have significant differences in estimating the expected rate of return.

$\mathrm{H}_{1}=$ the portfolio selection models will have significant differences in estimating expected rate of return.
Table 6. ANOVA

\begin{tabular}{|l|c|c|c|c|c|}
\hline & $\begin{array}{c}\text { Sum of } \\
\text { squares }\end{array}$ & df & $\begin{array}{c}\text { Mean } \\
\text { square }\end{array}$ & $F$ & Sig. \\
\cline { 1 - 4 } X2 between groups & 192.492 & 2 & 96.246 & & \\
\cline { 1 - 4 } Within groups & 883.080 & 57 & 15.493 & 6.212 & 0.004 \\
\cline { 1 - 4 } Total & 1075.572 & 59 & & & \\
\hline
\end{tabular}

The test is accepted at two stars level and by the point of Sig $=0.004, \mathrm{H}_{0}$ is rejected and it means three models are not similar to estimate expected rate of return.

Table 7. Alpha of Jensen model

\begin{tabular}{|l|c|}
\hline \multicolumn{1}{|c|}{ Models } & Alpha \\
\hline Excess return & 4.271030502 \\
\hline Fama and French's model & 7.76524227 \\
\hline CAPM & 8.315914478 \\
\hline
\end{tabular}

Table 8. T.K. Test

\begin{tabular}{|l|c|c|c|c|c|}
\hline \multirow{2}{*}{ Dependent $(\mathrm{I}) \mathrm{k}(\mathrm{J}) \mathrm{k}$ Variable } & \multirow{2}{*}{ Mean difference (I-J) } & \multirow{2}{*}{ Std. Error } & \multirow{2}{*}{ Sig. } & \multicolumn{2}{c|}{$95 \%$ Confidence interval } \\
\cline { 4 - 6 } & & & & Lower bound & upper bound \\
\hline $\mathrm{X}_{2}$ CAPM excess return & 4.04488 & 1.24469 & 0.005 & 1.0496 & 7.0401 \\
\hline CAPM Fama \& French & 0.55067 & 1.24469 & 0.898 & -2.4446 & 3.5459 \\
\hline Excess return Fama \& French & -3.49421 & 1.24469 & 0.018 & -6.4895 & -0.499 \\
\hline
\end{tabular}

Looking at Table 8, we find that CAPM has significant difference with Excess return at the level of 0.005 . In contrast, there is no difference between CAPM and Fama \& French, but there is sa ignificant level about 0.018 between Excess return and Fama \& French.

2.3. Real return of future season, $X_{3}$. It is expected to be deferential generating about real return between models at three months of future. The hypotheses are:

$\mathrm{H}_{0}=$ the portfolio selection models won't have significant differences in generating the real return (three monthly).

$\mathrm{H}_{1}=$ the portfolio selection models will have significant differences in generating the real return (three monthly).

Table 9. ANOVA

\begin{tabular}{|l|c|c|c|c|c|}
\hline & $\begin{array}{c}\text { Sum of } \\
\text { squares }\end{array}$ & df & $\begin{array}{c}\text { Mean } \\
\text { square }\end{array}$ & F & Sig. \\
\cline { 1 - 4 } $\begin{array}{l}X_{3} \text { between } \\
\text { groups }\end{array}$ & 57.737 & 2 & 28.869 & \multirow{2}{*}{0.552} & 0.579 \\
\cline { 1 - 4 } Within groups & 2981.048 & 57 & 52.299 & & \\
\cline { 1 - 4 } Total & 3038.785 & 59 & & \\
\hline
\end{tabular}

As significant level that is $0.579, \mathrm{H}_{1}$ is rejected and it means there are no differences between models in real return of three months of future. Nonetheless, according to Tukey-Kramer test, there is a bit difference between Excess return and CAPM that it isn't statistical significance.

Table 10. Alpha of Jensen model

\begin{tabular}{|l|c|}
\hline \multicolumn{1}{|c|}{ Models } & Alpha \\
\hline Excess return & 2.333426667 \\
\hline Fama and French's model & 0.438454808 \\
\hline CAPM & 0.106451293 \\
\hline
\end{tabular}

Table 11. T.K. Test

\begin{tabular}{|l|c|c|c|c|c|}
\hline \multirow{2}{*}{ Dependent (I)k (J)k variable } & \multirow{2}{*}{ Mean difference (I-J) } & \multirow{2}{*}{ Std. error } & \multirow{2}{*}{ Sig. } & \multicolumn{2}{c|}{$95 \%$ Confidence interval } \\
\cline { 4 - 6 } & & & & Lower bound & Upper bound \\
\hline$X_{3}$ CAPM excess return & -2.22698 & 2.2869 & 0.596 & 7.7302 & 3.2763 \\
\hline CAPM Fama \& French & -0.332 & 2.2869 & 0.988 & -5.8352 & 5.1712 \\
\hline Excess return Fama \& French & 1.89497 & 2.2869 & 0.687 & -3.6083 & 7.3982 \\
\hline
\end{tabular}


2.4. Real return of future year, $X_{4}$. We argue that there are significant differences between models as generating real return of future year. More formally:

$\mathrm{H}_{0}=$ the portfolio selection models won't have significant differences in generating the real return (yearly).

$\mathrm{H}_{1}=$ the portfolio selection models will have significant differences in generating the real return (yearly).
Table 12. ANOVA

\begin{tabular}{|l|c|c|c|c|c|}
\hline & Sum of squares & df & Mean square & $\mathrm{F}$ & Sig \\
\hline$X_{4}$ between groups & 395.819 & 2 & 197.910 & & \\
\cline { 1 - 4 } Within groups & 12365.223 & 57 & 216.934 & \multirow{2}{*}{0.912} & 0.407 \\
\cline { 1 - 4 } Total & 12761.043 & 59 & & & \\
\hline
\end{tabular}

Table 13. Alpha

\begin{tabular}{|l|c|}
\hline \multicolumn{1}{|c|}{ Models } & Alpha \\
\hline Excess return & 2.016387248 \\
\hline Fama and French's model & 0.983061836 \\
\hline CAPM & 0.207637153 \\
\hline
\end{tabular}

Table 14. T.K. Test

\begin{tabular}{|l|c|c|c|c|c|}
\hline \multirow{2}{*}{ Dependent $(\mathrm{I}) \mathrm{k}(\mathrm{J}) \mathrm{k}$ variable } & \multirow{2}{*}{ Mean difference (I-J) } & \multirow{2}{*}{ Std. error } & \multirow{2}{*}{ Sig. } & \multicolumn{2}{c|}{$95 \%$ Confidence interval } \\
\cline { 4 - 6 } & & & & Lower bound & Upper bound \\
\hline $\mathrm{X}_{4}$ CAPM excess return & -6.22706 & 4.65761 & 0.381 & -17.4352 & 4.9811 \\
\hline CAPM Fama \& French & -2.33622 & 4.65761 & 0.781 & -13.5444 & 8.8719 \\
\hline Excess return Fama \& French & 3.890804 & 4.65761 & 0.683 & -7.3173 & 15.0990 \\
\hline
\end{tabular}

Looking at Table 12 significant level is 0.407 that it lead the $\mathrm{H}_{1}$ to reject. According to Table 13, the Alpha of Excess returns model is about 2.01 and there is a difference between three models, that is, some extent.

2.5. Average of real returns of future season, $X_{5}$. There is an argue that there are significant differences between models to generate average of real returns of future season. More formally,

$\mathrm{H}_{0}=$ the portfolio selection models won't have significant differences to generate the real return (seasonal average).

$\mathrm{H}_{1}=$ the portfolio selection models will have

significant differences in generate the real return (seasonal average).

Table 15. ANOVA

\begin{tabular}{|l|c|c|c|c|c|}
\hline & Sum of squares & df & Mean square & $\mathrm{F}$ & Sig \\
\hline$X_{5}$ between groups & 25.803 & 2 & 12.901 & & \\
\cline { 1 - 4 } Within groups & 777.971 & 57 & 13.649 & \multirow{2}{*}{0.945} & 0.395 \\
\cline { 1 - 4 } Total & 803.733 & 59 & & & \\
\hline
\end{tabular}

Table 16. Alpha

\begin{tabular}{|l|c|}
\hline \multicolumn{1}{|c|}{ Models } & Alpha \\
\hline Excess return & 2.462385 \\
\hline Fama and French's model & 1.489674652 \\
\hline CAPM & 0.868971106 \\
\hline
\end{tabular}

Table 17. T.K. Test

\begin{tabular}{|l|c|c|c|c|c|}
\hline \multicolumn{1}{|c|}{ Dependent $(\mathrm{I}) \mathrm{k}(\mathrm{J}) \mathrm{k}$ variable } & \multirow{2}{*}{ Mean difference (I-J) } & \multirow{2}{*}{ Std. error } & \multirow{2}{*}{ Sig. } & \multicolumn{2}{c|}{ 95\% Confidence interval } \\
\cline { 4 - 6 } & -1.59341 & 1.16827 & 0.366 & -4.404 & 1.2179 \\
\hline$X_{5}$ CAPM excess return & -0.62070 & 1.16827 & 0.856 & -3.4321 & 2.1906 \\
\hline CAPM Fama \& French & 0.97271 & 1.16827 & 0.684 & -1.8386 & 3.7841 \\
\hline Excess return Fama \& French & &
\end{tabular}

Table 15 shows significant level is 0.395 and it means $\mathrm{H}_{1}$ is rejected. The return of Excess return model is about 2.46 and 1.489 for Fama and French's model there are differences between three models but not significant.

2.6. Differences between real return and expected rate of return at short term, $X_{5}$. We argue that the models are different about differential extent between real return and expected rate of return. More formally,

$\mathrm{H}_{0}=$ the portfolio selection models won't have significant differences to generate differential extent between real return and expected rate of return at short term.
$\mathrm{H}_{1}=$ the portfolio selection models will have significant differences to generate differential extent between real return and expected rate of return at short term.

Table 18. ANOVA

\begin{tabular}{|l|c|c|c|c|c|}
\hline & Sum of squares & $\mathrm{df}$ & Mean square & $\mathrm{F}$ & Sig \\
\hline $\mathrm{X}_{6}$ between groups & 461.058 & 2 & 230.529 & & \\
\cline { 1 - 4 } Within groups & 3555.571 & 57 & 62.378 & \multirow{3}{*}{3.696} & 0.031 \\
\cline { 1 - 4 } Total & 4016.629 & 59 & & & \\
\hline
\end{tabular}

Table 19. Alpha

\begin{tabular}{|l|c|}
\hline \multicolumn{1}{|c|}{ Models } & Alpha \\
\hline Excess return & -1.937603835 \\
\hline Fama and French's model & -7.326787462 \\
\hline CAPM & -8.209463186 \\
\hline
\end{tabular}


Table 20. T.K. Test

\begin{tabular}{|l|c|c|c|c|c|}
\hline \multirow{2}{*}{ Dependent $(\mathrm{I}) \mathrm{k}(\mathrm{J}) \mathrm{k}$ variable } & \multirow{2}{*}{ Mean difference (I-J) } & \multirow{2}{*}{ Std. error } & \multirow{2}{*}{ Sig. } & \multicolumn{2}{c|}{ 95\% Confidence interval } \\
\cline { 4 - 6 } & & & & Lower bound & Upper bound \\
\hline $\mathrm{X}_{6}$ CAPM excess return & -6.27186 & 2.49757 & 0.039 & -12.2821 & 0.2617 \\
\hline CAPM Fama \& French & -0.88268 & 2.49757 & 0.934 & -6.8929 & 5.1275 \\
\hline Excess return Fama \& French & 5.38918 & 2.49757 & 0.087 & -0.6210 & 11.3994 \\
\hline
\end{tabular}

Table 18 shows significant level is 0.031 and it means $\mathrm{H}_{0}$ is rejected. The Alpha of Excess return model is about -1.937 and -7.326 for Fama and French's model there are differences between three models on the level of one star.

\subsection{Differences between real return and expected} rate of return at long term, $\mathbf{X}_{7}$. It is expected that the models are different about differential extent between real return and expected rate of return. More formally,

$\mathrm{H}_{0}=$ the portfolio selection models won't have significant differences to generate differential extent between real return and expected rate of return at long term.
$\mathrm{H}_{1}=$ the portfolio selection models will have significant differences to generate differential extent between real return and expected rate of return at long term.

Table 21. ANOVA

\begin{tabular}{|l|c|c|c|c|c|}
\hline & Sum of squares & $\mathrm{df}$ & Mean square & $\mathrm{F}$ & Sig \\
\hline $\mathrm{X}_{7}$ between groups & 354.106 & 2 & 177.053 & & \\
\cline { 1 - 4 } Within groups & 2091.729 & 57 & 36.697 & \multirow{2}{*}{4.825} & 0.012 \\
\cline { 1 - 4 } Total & 2445.835 & 59 & & & \\
\hline
\end{tabular}

Table 22. Alpha

\begin{tabular}{|l|c|}
\hline \multicolumn{1}{|c|}{ Models } & Alpha \\
\hline Excess return & -1.808645502 \\
\hline Fama and French's model & -6.27556719 \\
\hline CAPM & -7.446943373 \\
\hline
\end{tabular}

Table 23. T.K. Test

\begin{tabular}{|l|c|c|c|c|c|}
\hline \multirow{2}{*}{ Dependent (I)k (J)k variable } & \multirow{2}{*}{ Mean difference (I-J) } & \multirow{2}{*}{ Std. error } & \multirow{2}{*}{ Sig. } & \multicolumn{2}{c|}{$95 \%$ Confidence interval } \\
\cline { 4 - 6 } & & & & Lower bound & Upper bound \\
\hline $\mathrm{X}_{7}$ CAPM excess return & -5.63803 & 1.91565 & 0.013 & -10.2481 & -1.0285 \\
\hline CAPM Fama \& French & -1.17138 & 1.91565 & 0.814 & -5.7812 & 3.4385 \\
\hline Excess return Fama \& French & 4.46692 & 1.91565 & 0.059 & -0.1429 & 9.0768 \\
\hline
\end{tabular}

Table 21 shows the models are not differences at short and long term. As sig is 0.012 , we can know $\mathrm{H}_{0}$ is rejected at level of two stars and there are significant differences between CAPM and Excess return models.

2.8. Differences between real return and market return at short term, $\mathbf{X}_{\mathbf{8}}$. We expect that the models are different about difference of real return and market return at short term. Thus,

$\mathrm{H}_{0}=$ the portfolio selection models won't have significant differences between difference of real return and market return at short term.

$\mathrm{H}_{1}=$ the portfolio selection models will have significant differences between difference of real return and market return at short term.

Table 24. ANOVA

\begin{tabular}{|l|c|c|c|c|c|}
\hline & Sum of squares & $\mathrm{df}$ & Mean square & $\mathrm{F}$ & Sig \\
\hline $\mathrm{X}_{8}$ between groups & 57.737 & 2 & 28.869 & & \\
\cline { 1 - 4 } Within groups & 2804.676 & 57 & 49.205 & \multirow{2}{*}{0.587} & 0.559 \\
\cline { 1 - 4 } Total & 2862.413 & 59 & & & \\
\hline
\end{tabular}

Table 25. Alpha

\begin{tabular}{|l|c|}
\hline \multicolumn{1}{|c|}{ Models } & Alpha \\
\hline Excess return & 1.499426667 \\
\hline Fama and French's model & -0.395545192 \\
\hline CAPM & -0.727548707 \\
\hline
\end{tabular}

Table 26. T.K. Test

\begin{tabular}{|l|c|c|c|c|c|}
\hline \multirow{2}{*}{ Dependent (I)k (J)k variable } & \multirow{2}{*}{ Mean difference (I-J) } & \multirow{2}{*}{ Std. error } & \multirow{2}{*}{ Sig. } & \multicolumn{2}{c|}{ 95\% Confidence interval } \\
\cline { 4 - 6 } & & & & Lower bound & Upper bound \\
\hline $\mathrm{X}_{8}$ CAPM excess return & -2.22698 & 2.21822 & 0.577 & -7.5649 & -3.1110 \\
\hline CAPM Fama \& French & -0.33200 & 2.21822 & 0.988 & -5.6700 & 5.0060 \\
\hline Excess return Fama \& French & 1.89497 & 2.21822 & 0.671 & -3.4430 & 7.2329 \\
\hline
\end{tabular}

There is no different between models, but Excess Return model has made a bit better return.

2.9. Differences between real return and market return at long term, $\mathbf{X}_{\mathbf{9}}$. We argue that the models are different about differences between real return and market return at long term. We predict that:

$\mathrm{H}_{0}=$ the portfolio selection models won't have significant differences between difference of real 
return and market return at long term.

$\mathrm{H}_{1}=$ the portfolio selection models will have significant differences between difference of real return and market return at long term.

Table 27. ANOVA

\begin{tabular}{|l|c|c|c|c|c|}
\hline & Sum of squares & df & Mean square & $\mathrm{F}$ & Sig \\
\hline$X_{9}$ between groups & 25.803 & 2 & 12.901 & 1.150 & 0.324 \\
\hline
\end{tabular}

\begin{tabular}{|l|l|l|l|l|l|}
\hline Within groups & 639.611 & 57 & 11.221 & & \\
\cline { 1 - 4 } Total & 665.414 & 59 & & & \\
\hline
\end{tabular}

Table 28. Alpha

\begin{tabular}{|l|c|}
\hline \multicolumn{1}{|c|}{ Models } & Alpha \\
\hline Excess return & 2.123785 \\
\hline Fama and French's model & 1.151074652 \\
\hline CAPM & 0.530371106 \\
\hline
\end{tabular}

Table 29. T.K. Test

\begin{tabular}{|l|c|c|c|c|c|}
\hline \multirow{2}{*}{ Dependent (I)k (J)k variable } & \multirow{2}{*}{ Mean difference (I-J) } & \multirow{2}{*}{ Std. error } & \multirow{2}{*}{ Sig. } & \multicolumn{2}{c|}{$95 \%$ Confidence interval } \\
\cline { 4 - 6 } & & & & Lower bound & Upper bound \\
\hline$X_{9}$ CAPM excess return & -1.59341 & 1.05930 & 0.297 & -4.1425 & 0.9557 \\
\hline CAPM Fama \& French & -0.62070 & 1.05930 & 0.828 & -3.1698 & 1.9284 \\
\hline Excess return Fama \& French & 0.97271 & 1.05930 & 0.631 & -1.5764 & 3.5218 \\
\hline
\end{tabular}

In long term, the models are similar.

2.10. Systematic risk (Beta), $X_{10}$. Systematic risk is one of the most important factors to analyze stocks and firms. On the other hand, beta is the best measure of risk and we argue the models are not same as risk measuring. We, therefore, predict the following:

$\mathrm{H}_{0}=$ the portfolio selection models won't have significant differences in measuring risk and beta. $\mathrm{H}_{1}=$ the portfolio selection models will have significant differences in measuring risk and beta.

Table 30. ANOVA

\begin{tabular}{|l|c|c|c|c|c|}
\hline & Sum of squares & df & Mean square & $F$ & Sig \\
\hline$X_{10}$ between groups & 104.171 & 2 & 52.086 & & \\
\cline { 1 - 3 } Within groups & 126.689 & 57 & 2.223 & 23.434 & 0.000 \\
\hline Total & 230.861 & 59 & & & \\
\hline
\end{tabular}

Table 31. T.K. Test

\begin{tabular}{|l|c|c|c|c|c|}
\hline \multirow{2}{*}{ Dependent $(\mathrm{I}) \mathrm{k}(\mathrm{J}) \mathrm{k}$ variable } & \multirow{2}{*}{ Mean difference (I-J) } & \multirow{2}{*}{ Std. error } & \multirow{2}{*}{ Sig. } & \multicolumn{2}{c|}{$95 \%$ Confidence interval } \\
\cline { 5 - 6 } & & & & Lower bound & Upper bound \\
\hline $\mathrm{X}_{10}$ CAPM excess return & 2.6305 & 0.47145 & 0.000 & 1.4960 & 3.7650 \\
\hline CAPM Fama \& French & 2.93487 & 0.47145 & 0.000 & 1.8004 & 4.0694 \\
\hline Excess return Fama \& French & 0.30436 & 0.47145 & 0.769 & -0.8301 & 1.4389 \\
\hline
\end{tabular}

There are significant differences between models to form portfolios with different risk that is measured by beta $(\beta)$.

\section{Conclusion}

According to results we are admit the major

hypotheses $\left(a_{1}, a_{2}\right)$, that were related together. Following we have seasonal average of returns of each models' portfolio, market return and free risk return. Then differences between models' return and market and free risk return are as following Table 32 .

Table 32. Returns and differences between variables

\begin{tabular}{|l|c|c|c|c|c|}
\hline \multicolumn{1}{|c|}{ Models } & Portfolio's return & Market return & Free risk return & Return of models' portfolio minus market return & Return of models' portfolio minus free risk return \\
\hline CAPM & 0.869 & 0.3386 & 4.25 & 0.5304 & -3.381 \\
\hline Fama \& French & 1.489 & 0.3386 & 4.25 & 1.1504 & -2.761 \\
\hline Excess return & 2.462 & 0.3389 & 4.25 & 2.1234 & -1.788 \\
\hline
\end{tabular}

Tbable 32 shows that there is 2.1234 difference between portfolios' return of Excess return model and return of market and it is a notable point from that model. In contrast, all models have negative result in comparison with free risk return. It can be cause of high interest rate at monetary market in IRAN.

According to Table 33, there are variance and semi variance of real return of future season that are generated by models. Variance represents total risk and semi variance represents downside risk. Excess return model has more downside risk. We also can calculate $\frac{\text { var }}{2}$ that is measure to comprise with semi variance. In Fama \& French model and Excess return model $\frac{\mathrm{var}}{2}>S E M V A R$ and we finding that there are skewness to right.

Table 33. Variance and semi variance

\begin{tabular}{|l|c|c|c|}
\hline \multicolumn{1}{|c|}{ Models } & Variance & Semi variance & Variance / 2 \\
\hline CAPM & 0.000695 & 0.000393 & 0.0003457 \\
\hline Fama \& French & 0.001666112 & 0.000675 & 0.0008333 \\
\hline Excess return & 0.001528509 & 0.000722 & 0.0007642 \\
\hline
\end{tabular}


In conclusion, the three models are able to be tested in capital market of Iran. There are significant differences between models in expected rate of return. excess return model creates portfolios better than the others by the point of return and level of risk.

\section{Notes}

1. CAPM.

2. Earning to price ratio.

3. Cash flow to price ratio.

4. Tehran dividend and price index.
5. $55 \times 20=1100$ samples and 20 points of five years.

\section{Highlights}

- We expect to find differences between CAPM, Fama and French and Excess return models as generating expected rate of return.

- According to return, systematic risk, and downside risk: there are significant differences between models.

- Excess return model has significant difference with others by the view of return, systematic risk, and downside risk.

\section{References}

1. Dennis, P., Perfect, S., Snow, K. \& Wiles, K. (1995). The Effects of Rebalancing on Size and Book-to-Market Ratio Portfolio Returns, Financial Analysts Journal, 51 (3), pp. 47-57. doi:http://dx.doi.org/10.2469/faj.v51.n3.1905.

2. Fama, E. \& MacBeth, J. (1973). Risk, Return and Equilibrium; Empirical Tests, Journal of Political Economy, 81 (3), pp. 607-636. doi:10.1086/260061.

3. Fama, E.F. (1998). Market Efficiency, Long Term Returns, and Behavioral Finance, Journal of Financial Economic, 49 (3), pp. 283-306. doi:http://dx.doi.org/10.1016/S0304-405X(98)00026-9.

4. Fama, E. \& French, K. (1992). The Cross Section of Expected Stock Returns, Journal of Finance, 47 (2), pp. 427465. doi:10.1111/j.1540-6261.1992.tb04398.x.

5. Fama, E. \& French, K. (1993). Common Risk Factors in the Returns on Stocks and Bonds, Journal of Financial Economics, 33 (1), pp. 3-56. doi:http://dx.doi.org/10.1016/0304-405X(93)90023-5.

6. Fama, E. \& French, K. (1995). CAPM Wanted Dead or Alive? The Journal of Finance, 51 (5), pp. 147-158.

7. Fama, E. \& French, K. (1998). Value Versus Growth; The International Evidence, The Journal of Finance, 53 (6), pp. 1975-1999. doi:10.1111/0022-1082.00080.

8. Fama, E. \& French, K. (2004). The Capital Asset Pricing Model; Theory and Evidence, Journal of Economic Perspectives, 18 (3), pp. 25-46. doi:10.1257/0895330042162430.

9. Haugen, R. (1993). Modern Investment Theory, Englewood Cliffs. N.J.: Prentice Hall.

10. Haugen, R. (1995). The New Finance; the Case Against Efficient Markets, Contemporary Issues in Finance. Englewood Cliffs. N.J.: Prentice Hall.

11. Jensen, M. (1968). The Performance of Mutual Funds in the Period 1945-1964, The Journal of Finance, 23 (2), pp. 389-416. doi:10.1111/j.1540-6261.1968.tb00815.x.

12. Lintner, J. (1965). The Valuation of Risk Assets and the Selection of Risky Investments in Stock Portfolios and Capital Budgets, Review of Economics and Statistics, 47 (1), pp. 13-37. doi:10.2307/1924119.

13. Markowitz, H. (1959). Portfolio Selection; Efficient Diversification of Investment. New York: Wiley.

14. Reilly, F. \& Brown, K. (2003). Investment Analysis and Portfolio Management. $7^{\text {th }}$ ed. New York: Wiley.

15. Rizwan, Q. \& Rehman, S. (2014). Applicability of Capital Assets Pricing Model on Pakistan Stock Markets, International Journal of Management and Business Researches, 4 (1), pp. 1-9.

16. Roll, R. (1983). Vas Ist das? The Turn of the Year Effect and the Return Premium of Small Firms, Journal of Portfolio Management, 9 (2), pp. 18-28. doi:10.3905/jpm.1983.18.

17. Roll, R. \& Ross, S. (1994). On the Cross Sectional Relation between Expected Returns and Betas, The Journal of Finance, 49 (1), pp. 101-121. doi:10.1111/j.1540-6261.1994.tb04422.x.

18. Sharpe, W. (1964). Capital Asset Prices; A Theory of Market Equilibrium under Conditions of Risk, The Journal of Finance, 19 (3), pp. 425-442. doi:10.1111/j.1540-6261.1964.tb02865.x.

19. Tudor, C. (2009). Firm Specific Factors as Predictors of Future Returns for Romanian Common Stocks; Empirical Evidence, Recent Researches in Business Administration, Finance and Product Management, 12 (4), pp. 73-75. 